\title{
MEMBENTUK KARAKTER GENERASI MUDA MELALUI INSTITUSI KELUARGA DI ERA DIGITAL
}

\author{
Oleh: Salmawaty RG \& Hilal Mahmud \\ Program Studi Manajemen Pendidikan Islam \\ E-Mail : hilalmahmud@iainpalopo.ac.id
}

\begin{abstract}
Abstrak
The main focus of this research is how to shape character of young generation through family institutions in digital era. The study, therefore, discusses the adopted parenting pattern and the role of family institutions in shaping character of young generation in digital era. Data obtained through questionnaires, interviews, observation and documentation studies. The population in this study is all students of SMP Negeri 9 Palopo which amounted to 597 people. Sampling technique used is Probability Sampling Technique based on Slovin formula so that the number of samples is 86 people. The results showed that the adopted parenting pattern is permissive, authoritarian, and authoritative.
\end{abstract}

Keywords: Family Institution, Personality of Young Generation, Digital Era

\section{A. PENDAHULUAN}

Institusi keluarga merupakan komponen penting dalam pembentukan generasi. Institusi keluarga merupakan unit terkecil dari masyarakat dan merupakan kelompok primer yang memainkan peranan paling penting dalam membentuk karakter individu. Keluarga terbentuk dari individu laki-laki dan perempuan, terkumpul dan tinggal bersama dipimpin oleh seorang kepala keluarga dalam keadaan saling ketergantungan (Harwantiyoko \& Katuuk, 1997). Keluarga memiliki fungsi menciptakan serta mempertahankan kebudayaan (Bailon \& Maglaya, 1978; Locke \& Burgess, 1953). Islam memandang institusi keluarga sebagai institusi pembentuk wajah masa depan generasi penerus bangsa (QS. at-Tahrim/66:6, QS. Thaha/20:132). Institusi keluarga merupakan pusat pembentukan budaya dan peradaban. Pandangan semacam ini mulai dipertanyakan seiring perubahan zaman yang begitu pesat dan dengan tekanan sosial, ekonomi, dan politik yang begitu kompleks. Setidaknya, hal ini terjadi di belahan dunia yang terbuka dimana Negara tidak membentengi masyarakatnya dari serangan budaya dan peradaban 'baru'.

Perubahan dan kemajuan ilmu pengetahuan dan teknologi begitu pesat berdampak pada seluruh aspek kehidupan, tidak terkecuali kehidupan keluarga. Keluarga tidak mampu menolak kepentingan di luar keluarga, bahkan telah menjadi wakil dari 
kepentingan pasar. Pasar telah mendikte selera keluarga. Pasar telah menghadirkan kebutuhan simbolis yang mengarah pada pembentukan status dan redefinisi identitas keluarga dan anggota-anggotanya. Batas-batas budaya mengalami pergeseran dan terkadang mengabaikan sentimen agama. Pergeseran ini melahirkan sistem sosial yang lebih terbuka. Keterbukaan menawarkan iklim kondusif bagi gerakan untuk mendorong pembentukan struktur sosial baru yang boleh jadi bertentangan dengan nilai-nilai keagamaan yang dianut.

Keluarga merupakan tempat pertama dalam kehidupan anak, dimana mereka belajar dan menyatakan diri sebagai makhluk sosial. Dalam keluarga umumnya anak ada dalam interaksi yang intim. Keluarga memberikan dasar pembentukan tingkah laku, watak, moral, dan pendidikan anak (Kartono, 2006: 62). Penelitian Jeb A. Booth (2008: 423-456) menemukan bahwa kenakalan remaja berhubungan dengan kontrol sosial dari orang tua. Baik buruknya ikatan seorang anak dengan orang tuanya dapat memengaruhi sikap anak itu sendiri. Ikatan keluarga yang kuat akan dapat menghindarkan anaknya dari kenakalan remaja. Sebaliknya, ikatan keluarga yang lemah bisa menyebabkan anak terjerumus ke dalam kenakalan remaja.

Membentuk generasi berkarakter di era digital melalui institusi keluarga sangat penting dan menarik untuk dikaji. Sejumlah penelitian telah dilakukan untuk mengkaji peran institusi keluarga dalam membangun generasi berkarakter. Penelitian Emilie Phillips Smith (2003) menguji korelasi antara faktor keluarga, sekolah, masyarakat dengan sikap rasial, etnis dan prestasi akademik. Smith menyimpulkan bahwa ketika seorang siswa memiliki latar belakang ras-etnis yang baik, maka ia memiliki karakter dan akademik yang baik pula. Studi ini menunjukkan bahwa keluarga, sekolah, dan masyarakat merupakan faktor penting yang berkaitan dengan sikap rasial-etnis siswa dan juga untuk prestasi akademik mereka. Penelitian Casmini (2007:47) lebih menekankan pada peran orang tua dalam membentuk generasi berkarakter. Pola asuh orang tua dalam keluarga akan berpengaruh terhadap perkembangan anak. Sikap perilaku dan kebiasaan orang tua sehari-hari akan dilihat, dinilai dan ditiru oleh anak-anaknya sehingga mereka akan berperilaku sebagaimana ditunjukkan orang tuanya. S. E. Oladipo (2009:149-156) mengungkapkan bahwa pendidikan moral anak dibagi berdasarkan pembagian tanggung jawab. Lembaga-lembaga harus saling berinteraksi dalam memberikan pendidikan moral anak. Pendidikan moral bukan hanya tanggung jawab orang tua dan lembaga saja, tetapi semua pihak harus bertanggung jawab. Penelitian Dewi Umayami (2013:71) menyimpulkan bahwa mengembangkan sikap kemandiriran seorang anak memerlukan metode atau pola asuh. Pemilihan metode atau pola asuh yang tepat akan mampu menimbulkan kemandirian seorang anak.

Naimeh (2012) mengemukakan bahwa peran orang tua sebagai pendidik bagi anak-anak mereka merupakan keharusan karena anak sangat membutuhkan: 1) mencintai 
dan dicintai; 2) perlindungan hingga merasa aman; 3) bimbingan; 4) diakui; 5) disiplin. Dalam melakukan perannya orang tua harus memahami terlebih dahulu karakter dasar remaja. Fuad Ihsan (2001:58) menjelaskan bahwa tugas dan tanggung jawab orang tua dalam keluarga terhadap pendidikan anak-anaknya lebih bersifat pembentukan watak dan budi pekerti, latihan keterampilan dan pendidikan sosial. Izzaty (2013) menyimpulkan bahwa pendidikan karakter tidak dapat diwujudkan tanpa penanaman nilai-nilai karena nilai adalah motivasi dalam segala perbuatan dan dalam pelaksanaannya nilai dijabarkan dalam bentuk kaidah atau norma. Keluarga membutuhkan penerapan pola asuh yang tepat dalam membentuk karakter dan keperibadian anak di era digital ini.

Tulisan ini merupakan hasil penelitian yang akan membentangkan bagaimana membentuk generasi berkarakter melalui institusi keluarga di era digital. Pembahasan akan mengemukakan pola asuh yang diterapkan dan peran institusi keluarga dalam membentuk generasi berkarakter di era digital.

\section{B. POLA ASUH INSTITUSI KELUARGA}

Pola asuh institusi keluarga merupakan cara mendidik orang tua kepada anaknya baik secara langsung maupun secara tidak langsung. Cara mendidik secara langsung artinya bentuk-bentuk asuhan orang tua yang berkaitan dengan pembentukan karakter anak, kecerdasan dan keterampilan yang dilakukan secara sengaja baik berupa perintah, larangan, hukuman, penciptaan situasi maupun pemberian hadiah sebagai alat pendidik. Cara mendidik secara tidak langsung adalah contoh kehidupan sehari-hari baik tutur kata, sampai kepada adat kebiasaan dan pola hidup, baik itu hubungan dalam keluarga maupun di masyarakat yang ditujukkan oleh institusi keluarga. Berdasarkan hasil angket ditemukan bahwa institusi keluarga peserta didik pada SMP Negeri 9 Palopo menerapkan 3 tipe pola asuh yaitu

\section{Pola Asuh Permissive}

Berdasarkan hasil angket ditemukan bahwa terdapat 41,9\% institusi keluarga yang kadang-kadang menerapkan pola asuh permissive ditandai dengan indikator: (a) membebaskan anak tanpa pengawasan (59,3\%); (b) tidak mempedulikan sikap maupun tingkah laku anak (37,3\%); (c) tidak menghukum anak ketika melakukan kesalahan (44,2\%); (d) tidak memuji jika anak berprestasi (59,1\%); (e) intensitas berkomunikasi rendah (45,5\%); dan (f) segala keputusan diserahkan kepada anak (41,9\%). Fakta ini sangat menghawatirkan, mengingat generasi muda saat ini berada pada era digital. Generasi Digital (Digital Native) adalah generasi yang sangat fasih dengan bahasa global dan sangat akrab dengan informasi dan pengetahuan global melalui internet. Pikiran dan perasaan para Nitizen ini diekspresikan dalam dunia mereka, dunia virtual/maya. Bagi generasi digital, rasanya aktivitas mereka sehari-hari tidak lengkap jika tidak berinteraksi 
dengan Apple atau sejenisnya (Isaacson, 2014). Mereka berinteraksi, sharing, membuat dan berbagi konten melalui situs jejaring sosial. Chatting yang tiga puluh tahun yang lalu hanya dapat mereka lakukan di warnet, kini dapat dilakukan kapan saja dan dimana saja berkat teknologi Android. Melalui dunia maya mereka dengan mudah mendapat informasi yang diinginkan. Bagi generasi digital, cukup lewat jari, apapun yang diinginkan akan begitu mudah tersaji di depan mata. Dunia betul-betul sudah dalam genggaman. Dunia semakin kecil. Dunia betul-betul sudah selebar daun kelor. Akibatnya, sikap dan tindakan mereka merujuk kepada informasi dunia virtual yang boleh jadi bertentangan dengan nilainilai dan norma ajaran agama yang dianut sebelumnya.

Dalam peneltian ini ditemukan bahwa terdapat $59,3 \%$ orangtua membebaskan anak tanpa pengawasan. Membebaskan anak tanpa pengawasan bisa melahirkan berbagai problem institusi keluarga dalam upaya membentuk karakter generasi muda. Sikap dan perilaku anak tidak lagi merujuk pada nilai-nilai dan norma yang dianut sesuai dengan kebiasaan, adat dan norma yang dianut oleh keluarga sebelumnya. Kurangnya komunikasi mendalam antara anak dan orang tua dapat berdampak negatif pada perkembangan emosi anak. Padahal, obrolan mendalam antara orang tua dan anak juga bisa membantu anak mengendalikan perasaannya. Anak yang tidak diajak berkomunikasi dengan orangtuanya cenderung merasa jiwanya hampa sehingga mereka akan mencari orang lain untuk mengisi kekosongan tersebut. Idola mereka bergeser dari orangtua dalam institusi keluarga kepada tokoh idola yang setiap saat mereka berinteraksi di dunia maya. Intensitas berkomunikasi mereka lebih dominan di dunia maya sehingga informasi yang mengisi ruang berpikir mereka adalah informasi dunia maya. Hal ini menunjukkan terjadinya perubahan peran institusi keluarga yang jauh bergeser dari tatanan lama. Suatu tatanan yang melahirkan cara baru dalam melihat diri sendiri dan orang lain di dalam konteks yang berbeda yang oleh Berger dan Luckmann (1991) dan Geerzt (1973) sebutkan sebagai pencarian makna.

Terdapat $44,2 \%$ orangtua tidak menghukum anaknya yang telah melakukan kesalahan. Dengan alasan demi kepentingan anak itu sendiri kadang menghukum anak memang tidak bisa dihindari. Menghukum anak sebenarnya hanya salah satu pola dari sekian banyak pola dari pendidikan anak agar anak terkendali perilakunya. Hukuman pada anak yang tidak dilakukan dengan cara yang tidak benar dapat berdampak negatif pada anak. Ironisnya, terdapat 59\% orangtua tidak memberikan pujian atau hadiah ketika anaknya yang berprestasi. Padahal, penghargaan atas prestasi anak dapat memotivasi mereka untuk mempertahankan atau makin meningkatkan prestasi yang telah diraihnya. Generasi muda di era digital ini sangat membutuhkan arahan dan perhatian dari orang tua. Semakin bertambah umur seorang anak akan membuat dia semakin ingin tahu lebih jauh tentang apa yang ingin mereka ketahui sehingga dibutuhkan orang tua yang dapat mengawasi, serta memperdulikan sikap dan perilaku anak. 
Gaya pengasuhan permissive merupakan gaya pengasuhan di mana orang tua kurang terlibat dengan segala aktifitas anak, bahkan tidak terlalu menuntut atau mengontrol mereka. Gaya pengasuhan ini bisa saja berdampak pada sikap-sikap yang negatif pada anak. Pola asuh permissive dapat berdampak kepada anak menjadi kurang percaya diri, mau menang sendiri, suka melukai perasaan orang lain, tidak mandiri dan kurang bertanggung jawab. Orangtua yang selalu mengabulkan permintaan anaknya tanpa pernah menolaknya, berdampak pada perilaku anak yang akan memaksa orang tua untuk selalu memenuhi keinginannya. Pada tahap tertentu, ketika anak telah memiliki kematangan karakter, pola asuh permissive dapat diterapkan. Kohlberg (dalam Flemming, 2016) menjelaskan bahwa pembentukan karakter anak harus disesuaikan dengan tahapan-tahapan pertumbuhan dan perkembangan anak karena perkembangan karakter anak tidak dapat berbalik. Ketika suatu tahapan telah dicapai oleh seseorang tidak mungkin kembali mundur ke tahap sebelumnya. Pola asuh permissive bisa saja memiliki dampak positif khususnya jika diterapkan kepada anak yang sedang memasuki masa remaja. Dengan pola asuh permissive ini dapat melatih anak yang memasuki masa remaja menjadi insan yang mandiri. Selain itu, anak tersebut juga dapat merasa hidupnya tidak terkekang oleh aturan-aturan dari orang tua.

\section{Pola asuh authoritarian}

Hasil penelitian ini menunjukkan bahwa orangtua selalu menerapkan peraturan yang keras terhadap anak (31,3\%). Orang tua yang selalu menerapkan peraturan yang keras dan bahkan tidak memberikan hak kepada anak untuk mengeluarkan pendapat $(60,1 \%)$ menyebabkan anak menjadi tidak berani mengeluarkan pendapat, pasif, kurang berinisiatif bahkan cenderung ragu-ragu dalam mengambil keputusan dalam segala hal. Orang tua seringkali mengancam dan menghukum anaknya ketika membangkang pada orang tua(44,2\%). Sebaiknya orang tua menghindari kemarahan yang berlebihan kepada anak-anak pada saat melakukan kesalahan. Orang tua kadang-adang memaksakan aturan dan disiplin agar anak-anak mengikutinya tanpa mempertanyakan baik dan buruknya (48,8\%). Jika anak-anak gagal melakukan sesuatu biasanya dikenakan hukuman (46,5\%). Kedisiplinan dapat dilatih sejak dini melalui pola asuh yang diterapkan orang tua. Melalui pola asuh dengan disiplin yang baik, anak akan mengetahui bagaimana membiasakan diri melakukan hal-hal secara teratur dan terjadwal. Sebenarnya, penerapan disiplin yang ketat dapat menumbuhkan rasa tanggungjawab pada diri anak.

Seperti halnya pola asuh permissive, pola asuh authoritarian ini juga memiliki dampak yang negatif terhadap karakter anak. Anak dapat merasa tertekan dan berdampak pada ketidak-percayaan anak kepada orang tuanya. Pada umumnya, anak akan tumbuh sebagai anak yang kurang percaya diri, agresif, dan bersikap mengganggu teman- temannya. Namun penelitian yang dilakukan oleh Subhan El Hafiz 
(http://journal.uad.ac.id/index. php/HUMANITAS/article/download/3842/2110, diakses tanggal 15 Januari 2017) menunjukkan bahwa pola asuh otoriter tidak selalu berdampak negatif bagi pembentukan karakter anak. Pola asuh otoriter dapat menjadi pola asuh yang bermanfaat bagi pembentukan karakter anak apabila pola asuh tersebut diterapkan oleh ibu dan sebaliknya berdampak negatif jika diterapkan oleh ayah. Penelitian El Hafiz menyimpulkan bahwa pola asuh authoritarian dari ibu tidak perlu dianggap sebagai sesuatu yang berbahaya bagi perkembangan karakter anak karena pola asuh ini terbukti memberi manfaat positif terhadap kematangan emosi anak remaja jika diterapkan oleh ibu. Sebaliknya, jika pola asuh itu diterapkan oleh ayah maka perlu didukung dengan kesabaran anak dan pola asuh yang juga authoritarian dari ibu. Orang tua tetap perlu melatihkan kemampuan sabar pada anak agar dampak negatif dari pola asuh authoritarian dapat dihindari dan diperoleh dampak positif dari pola asuh authoritarian tersebut.

\section{Pola asuh authoritative}

Berdasarkan hasil angket ditemukan bahwa terdapat 41,9\% orangtua kadang-kadang menerapkan pola asuh authoritative yang ditandai dengan indikator: (a) menentukan peraturan-peraturan dengan memperhatikan dan mempertimbangkan keadaan, perasaan dan pendapat anak (44,2\%); (b) sering berkomunikasi dengan anak (10,5\%); (c) memberikan kesempatan kepada anak untuk mengemukakan pendapatnya $(60,2 \%)$; (d) mendukung anak dalam setiap kegiatan yang dilakukannya (33,7\%); (e) memberikan peringatan jika anak melakukan kesalahan (39,6 \%); (f) mengontrol semua kegiatan yang dilakukan oleh anak (46,9\%); (g) mengakui kemampuan yang dimiliki anak $(45,3 \%)$.

Dalam penelitian ini terdapat $44,2 \%$ orangtua menentukan peraturanperaturan dengan memperhatikan dan mempertimbangkan keadaan, perasaan dan pendapat anak. Hanya saja intensitas komunikasi mereka rendah (10,5\%). Padahal, orangtua memerlukan intensitas komunikasi yang cukup dalam menetapkan aturan, memberikan batasan-batasan, serta menjelaskan kenapa anak tidak boleh melakukan suatu tindakan yang dilarang. Apalagi dalam memberikan dukungan dan mengontrol kegiatan yang dilakukan anak, orangtua memerlukan intensitas komunikasi yang cukup. Intensitas komunikasi yang rendah ini terjadi bisa karena orangtua memberikan kesempatan kepada anaknya untuk mengemukakan pendapat dan mengakui kemampuan yang dimiliki anak $(45,3 \%)$.

Memberikan kebebasan kepada anak untuk memilih apa yang dikehendaki dan apa yang diinginkannya dan terbaik bagi dirinya karena sikap demokratis orangtua, pada dasarnya, merupakan sikap yang dapat mendukung sikap percaya diri anak. Apalagi jika diiringi dengan kepercayaan yang tinggi atas kemampuan yang mereka miliki. Mereka diberi kesempatan untuk belajar bertanggungjawab dengan apa yang telah dilakukannya 
dan juga diberi kesempatan untuk memilih jalan hidupnya. Tetapi semua itu harus dilakukan dengan meningkatkan intensitas komunikasi untuk meyakinkan mereka bahwa mereka dipercaya memiliki kemampuan. Intensitas komunikasi yang tinggi dapat pula menunjukkan bahwa mereka diperhatikan dan didengarkan saat anak berbicara. Bila berpendapat orang tua memberikan kesempatan untuk mendengarkan pendapatnya. Mereka dilibatkan dalam pembicaraan terutama yang menyangkut dengan kehidupan anak itu sendiri.

Dampak yang ditimbulkan dari pola asuh Authoritative (demokratis) ini adalah anak akan tumbuh menjadi pribadi yang percaya diri, mandiri, dapat mengontrol diri, berani, dan menghargai pendapat orang lain. Hasil penelitian ini sejalan dengan teori Diana Baumriend (1991:56-95) yang menunjukkan bahwa pola asuh Authoritative cenderung bersifat netral, dimana orang tua memberikan dorongan kepada anak untuk bersikap mandiri, namun masih menerapakan batas dan kendali pada tindakan mereka. Anak yang memiliki orang tua yang otoritatif akan memiliki sifat yang ceria, bisa mengontrol diri, mandiri, memiliki prestasi dan sikap sosial yang bagus, disenangi oleh teman-temannya dan bisa mengatasi masalahnya sendiri. Pengasuhan yang diberikan oleh orang tua lebih mengutamakan kasih sayang, kebersamaan, musyawarah, saling pengertian dan penuh keterbukaan keterbukaan. Jika anak-anak dibesarkan dan diasuh dengan pola asuh yang demokratis, niscaya dapat tumbuh dan berkembang dengan baik. Seluruh potensi yang dimiliki anak dapat dikembangkan secara optimal.

\section{PERAN INSTITUSI KELUARGA DALAM MEMBENTU KARAKTER GENERASI DIGITAL}

Para pakar psikologi menyebutkan anak-anak yang dilahirkan antara tahun 1995-2009 dikenali sebagai generasi z yaitu generasi yang lebih mementingkan pengetahuan tentang teknologi. Mereka lahir bersama perangkat ICT. Dalam aktivitas kesehariannya agaknya mereka menafikan penggunaan kertas. Mereka adalah Generasi Tanpa Kertas (No Paper generation). Generasi Z berada dalam dunia maya dan mampu terhubung dengan siapa pun yang dikehendaki melalui internet. Mereka boleh jadi dibesarkan dalam ruang sempit tetapi dapat menembus luas ke dunia virtual, dunia digital dengan adanya era teknologi informasi dan komunikasi. Yohana Yembise, Menteri Perempuan dan Perlindungan Anak, mengemukakan fakta bahwa anak Indonesia yang mengakses internet sebanyak 25 ribu orang perhari (Sindo, 20/9). Ini tentu suatu jumlah yang sangat fantastis.

Generasi Digital populer juga dengan sebutan Generasi Gadget, yaitu generasi yang memiliki ketergantungan luar biasa pada alat berteknologi komputer. Mereka tidak bisa berbuat banyak dalam kehidupannya tanpa kehadiran gadget di dekat mereka. Bahkan banyak di antara mereka yang kehilangan semangat, gelisah dan seolah tidak 
mampu berbuat apa-apa jika tidak membawa gadget. Para pemilik gadget nampaknya berasumsi bahwa segala problem yang dihadapi dalam kehidupan sehari-hari, jawabannya dapat ditemukan dengan mudah di sumber digital yang memang sepertinya tersedia banyak sekali di situs jejaring. Apa saja yang mereka butuhkan, mereka sangat mengandalkan dunia maya (virtual). Yang lebih fatal adalah semua informasi dari situs internet seolah kebenaran yang tidak diragukan.

Memang di samping bermanfaat, kehadiran gadget juga menghadirkan dampak buruk, terutama untuk generasi muda. Ternyata, kajian ilmiah membuktikan bahwa anak yang terlalu dipengaruhi oleh gadget akan kehilangan kecerdasan sosial, kemampuan berkomunikasi serta sikap perilaku sesuai norma nilai kemanusiaaan. Pakar psikologi perkembangan anak mengkhawatirkan gadget akan menjadikan mereka seperti sebuah mesin yang kehilangan ciri- ciri kemanusiaannya karena gadget tidak mampu memberikan sentuhan, belaian dan menunjukkan kasih sayang sebagaimana keluarga berikan. Bila mereka berhadapan dengan komputer, gadget, dan atau televisi, mereka akan melupakan hubungan kemanusiaan. Mereka lebih asyik dengan diri mereka sendiri. Yang paling dikhawatirkan adalah mereka akan kehilangan tanggungjawab sosial. Bila bertemu dengan keluarga, tidak ada rasa bersalah jika tidak menyapa dengan salam. Tidak tergerak hatinya membantu jika ada seseorang yang membutuhkan pertolongan.

Dampak buruk lainnya yang dapat menimpa generasi digital ini adalah kecenderungan memudarnya nilai-nilai budaya asli bangsa. Mengurangi ikatan moral dalam hubungan sosial. Sering ditemukan sekelompok orang atau keluarga berada pada suatu tempat yang sama, tetapi tidak saling menyapa. Mereka sibuk masing-masing dengan aktivitasnya. Mereka berdekatan tetapi jauh. Interaksi dengan dunia luar melalui gadget mengalahkan interaksi dengan anggota keluarga. Bahkan, dengan adanya teknologi canggih kebiasaan silaturrahmi, bertemu langsung digantikan dengan teknologi informasi. Kondisi tersebut memang praktis tetapi sentuhan, senyuman tulus, dan canda ceria akan sulit ditemukan melalui teknologi tersebut. Yang lebih fatal adalah sebagian orang memanfaatkan teknologi internet untuk tujuan-tujuan kejahatan. Hampir setiap saat berita tentang cybercrime, cyber-tresspass, pornografi, dan cyber-talking dipertontonkan melalui televisi atau media sosial lainnya.

Dalam upaya membentuk karakter generasi muda di era digital ini institusi keluarga memegang peranan penting. Pembentukan karakter anak meliputi pelaksanaan shalat fardhu, pelaksanaan shalat sunnah, berdoa setiap memulai kegiatan, pulang sekolah tepat waktu, menyelesaikan tugas tepat waktu, mengerjakan tugas sesuai tanggung jawabnya, menaati perkataan orangtua, mengucapkan salam ketika berangkat sekolah dan tiba di rumah, bergotong royong di lingkungan sekitar.

Dalam penelitian ini terdapat $64 \%$ keluarga melaksanakan sholat fardhu di rumah. $14,4 \%$ orangtua mewajibkan anak-anaknya shalat fardhu di masjid terdekat. 
Sayangnya, hanya 16\% keluarga yang memiliki kesempatan shalat berjamaah di rumah dan $12 \%$ yang memiliki kesempatan bersama anak shalat berjamaah di masjid karena alasan kesibukan kerja. Pelaksanaan shalat sunnah di rumah tidak di bawah control orangtua sehingga tidak ada anak yang melaksanakan shalat sunnah di rumah. Hal ini juga disebabkan oleh contoh dan pembiasaan yang sangat kurang. Hanya sedikit (16\%) keluarga yang memiliki kesempatan shalat berjamaah di rumah. Shalat sunnah di masjid sebanyak jumlah keluarga yang memiliki kesempatan bersama anak shalat berjamaah di masjid (12\%). Ini menunjukkan bahwa peran orangtua dalam pembentukan karakter sangat penting melalui contoh dan pembiasaan.

Karakter disiplin dan tanggung jawab anak dapat ditunjukkan melalui kegiatan, antara lain: pulang ke rumah tepat waktu, menyelesaikan tugas tepat waktu, mengerjakan tugas sesuai tanggung jawabnya. Dalam penelitian ini ditemukan hanya $23 \%$ anak yang pulang ke rumah tepat waktu dengan berbagai alasan. 24\% anak anak terlambat tiba di rumah karena menyelesaikan tugas di rumah teman. $23 \%$ anak menghabiskan waktu di warung internet. 32\% anak menghabiskan waktu jalan-jalan di mall. Selebihnya tidak memberikan informasi yang jelas. Kondisi ini rentan dimanfaatkan anak untuk terlibat pada kegiatan-kegiatan negatif. Tanpa kontrol yang intens dari orangtua dapat berakibat pada kebiasaan sikap dan perilaku buruk. Kedekatan orangtua dan anak tidak dapat ditumbuhkan. Padahal, kedekatan dan keterlibatan orangtua terhadap semua aktivitas anak merupakan aspek-aspek yang potensial dalam membangun karakter anak. Kedekatan (attachment) keterlibatan (involvement) orangtua dengan anak mereka memberikan kontribusi besar terhadap pencegahan terhadap prilaku menyimpang, dan mendukung terbinanya sikap positif anak. W. A. Gerungan (2010:295) mengemukakan bahwa jika orang tua kurang memiliki banyak waktu yang luang untuk anak-anak mereka, maka hal ini juga dapat dipastikan keluarga tersebut sudah tidak utuh lagi. Faktor inilah yang akan menyebabkan seorang anak mudah terjerumus dengan hal-hal yang negatif atau terjebak dalam pergaulan bebas. Namun, semua ini juga membutuhkan dukungan positif dari masyarakat sekitar agar bisa terealisasi dengan sempurna.

Sikap santun dan peduli dapat ditunjukkan melalui sikap: mengucapkan salam ketika berangkat sekolah dan tiba di rumah, membantu pekerjaan keluarga di rumah, bergotong royong di lingkungan sekitar. Penelitian ini menunjukkan bahwa terdapat $43 \%$ anak yang mengucapkan salam ketika berangkat sekolah dan tiba di rumah. 24\% anak membantu pekerjaan keluarga di rumah. 23\% anak bergotong royong di lingkungan sekitar. Sikap santun dan peduli penting dibentuk dalam institusi keluarga melalui interaksi anggota keluarga yang saling memberi contoh dan pembiasaan. Santrock (2007:158-159) menjelaskan bahwa setiap keluarga adalah suatu sistem atau suatu kesatuan yang dibentuk oleh bagian-bagian yang saling berhubungan dan berinteraksi. Hubungan dalam keluarga juga tidak pernah hanya berlangsung satu arah. Setiap anggota keluarga adalah 
partisipan dalam beberapa subsistem yang bisa bersifat dyadic (melibatkan dua orang) dan juga bisa bersifat polyadic (melibatkan lebih dari dua orang). Subsistem-subsistem ini saling berinteraksi dan memengaruhi baik secara lansung maupun tidak langsung.

Dalam Islam institusi keluarga dibangun di atas ikatan suci, kasih sayang, dan saling menentramkan (QS. Ar-Rum/30:21). Dalam setiap doa yang dipanjatkan ke hadhirat Allah swt., setiap individu muslim mengharapkan agar generasi yang dibinanya bahagia di dunia dan akhirat. Karakter generasi yang akan dibentuk adalah generasi yang bahagia di dunia dan akhirat. Untuk mencapai kehidupan bahagia dunia dan akhirat maka generasi ini perlu memahami tujuan hidup sebagai muslim. Islam dengan jelas menjadikan hidup manusia di atas muka bumi ini dengan tujuan yang asasi yaitu untuk beribadah kepada Allah (QS. az-Zariyat/51: 51) dan menjadi Khalifah Allah bagi tujuan mentadbir dan memakmurkan muka bumi ini (QS. al-Baqarah/2: 30-33). Dengan demikian, dalam upaya membentuk karakter generasi muda maka institusi keluarga harus mempersiapkan diri menjalankan tugas hakiki dan tanggungjawabnya sebagai pentadbir rumah tangga yaitu memakmurkan institusi keluarga atau dalam konteks yang lebih luas ialah memakmurkan bumi (QS. Hud/11: 61).

Institusi keluarga mempunyai peranan yang sangat penting dalam membangun karakter generasi muda. Dalam semua budaya masyarakat tanggung jawab pengasuhan, pendidikan, dan penjagaan anak dibebankan pada institusi keluarga (Nock, 1992). Bahkan, dalam Islam pembentukan karakter generasi ditentukan oleh upaya institusi keluarga (QS. At-Tahrim/66:6). Namun, Perubahan sosial berakibat pada kecenderungan perubahan peranan institusi keluarga. Institusi-institusi lain telah mengambil alih sebagian peranan institusi keluarga. Otoritas institusi keluarga di Era Digital ini menjadi melemah, bahkan mulai mengalami kehilangan otoritasnya. Di Era Digital ini lokasi keluarga mulai bergeser keluar batas-batas keluarga. Kepala keluarga yang pada awalnya memiliki otoritas yang hampir tak terbatas dalam mengatur sikap dan tindakan ideal kemudian harus tidak berdaya menghadapi otoritas di luar institusi keluarga. Pusat kekuatan baru di luar institusi keluarga telah merubah dan membangun kekuatan baru pada anggota keluarga untuk melakukan pembangkangan terhadap nilai dan norma yang telah disepakati dan berlaku dalam institusi keluarga sebelumnya.

Kehadiran otoritas baru di luar institusi keluarga melahirkan bentuk-bentuk solidaritas baru dengan logika yang berbeda sesuai dengan agen sosial yang terlibat dalam proses konstruksinya. Nilai tidak lagi dikonstruksikan dengan harmoni tetapi dengan serangkaian negosiasi. Keluarga kemudian didefinisikan oleh otoritas baru di luar institusi keluarga sebagai lokasi komsumsi. Berbagai mode produksi baru melalui kekuatan program pasar melibatkan anggota keluarga dalam proses komsumsi massal. Model pakaian yang sangat potensial menggugat nilai kesopanan ditawarkan pasar dan mendapat pengesahan dalam institusi keluarga. Beragam jenis smartphone, mobil mewah, 
dan berbagai produk modern yang menunjukkan kelas dan status sosial telah menjadi menu wajib anggota keluarga. Pasar telah meghadirkan kebutuhan-kebutuhan simbolis yang mengarah pada pembentukan identitas dan status sosial yang berakibat pada pembangkangan terhadap nilai dan norma tradisional. Pasar berhasil menawarkan berbagai bentuk pilihan telah memberikan kekuatan individual para anggota keluarga untuk melakukan negosiasi nilai dan pengabsahan berbagai tindakan yang boleh jadi bertentangan dengan nilai dan norma yang pada awalnya dianut oleh institusi keluarga.

Kemajuan teknologi informasi pada satu sisi memberikan manfaat bagi kemajuan keluarga, pada sisi lain dapat mengancam peran penting institusi keluarga. Terlaporkan bahwa sebanyak 120 juta smartphone terjual pada bulan Agustus 2014 di kawasan Asia Tenggara. Singapura, Malaysia, Thailand, Filipina, Indonesia, Vietnam, dan Kamboja. Indonesia memimpin sebagai negara dengan pertumbuhan penjualan paling tinggi hingga 70\% (http://dailysocial.net/Oktober 2014). Dapat diasumsikan bahwa sebanyak itulah orang yang dapat terpengaruh baik positif maupun negatif dari situs jejaring sebagai penyedia informasi. Institusi keluarga selayaknya mempertimbangkan fakta ini dalam upaya membentuk karakter generasi di era digital ini. Pemanfaatan teknologi informasi tidak mungkin terhindarkan maka peran institusi keluarga bukan melawan dan menghilangkan tetapi mengelola dan mengarahkan perilaku generasi digital ini agar dapat terampil mendapatkan dan menguasai informasi, ilmu dan pengetahuan yang benar dan bertanggung jawab. Untuk itu setiap keluarga mau membuka diri menerima kehadiran teknologi informasi, dan berusaha semaksimal mungkin untuk memenangkan pengaruhnya dalam membagun karakter generasi digital.

Upaya membentuk karakter generasi muda bukan tanpa rintangan. Generasi di Era Digital ini telah menikmati berbagai kemudahan dan kenikmatan dunia yang sengaja Allah swt ciptakan untuk menguji hamba-Nya siapa yang terbaik diantara mereka (QS. alKahfi/18:7). Sebagai manusia, generasi digital ini memiliki sejumlah kelemahan. Kemudahan dan kenikmatan duniawi sering membuat mereka lupa tujuan penciptaannya, yaitu mengabdi (QS. Al-Dzariyat/51:51). Apabila mendapat kesenangan maka mereka akan berpaling dan menjauhkan diri dari kebenaran bahkan menunjukkan kesombongan. Apabila ditimpa kesusahan maka mereka berkeluh kesah dan putus asa (QS. AlIsra'/17:83, QS. Al-Ma'arij/70: 19). Apa pun yang dikerjakan selalu baik dalam pandangan mereka (QS. Yunus/10:12). Mereka lupa bahwa apa pun yang dilakukan di dunia ini akan dipertanggungjawabkan di yaumul akhir (QS. Al-Qiyamah/75:36). Kelemahan-kelemahan tersebut patut dipertimbangan oleh institusi keluarga dalam mempersiapkan diri membentuk sahsiah generasi cemerlang.

Terdapat sejumlah peran yang dapat dijalankan institusi keluarga dalam membentuk karakter generasi digital ini. Pertama, membina rumah tangga bahagia (QS. An-Nisa/4: 34). Ibu sebagai institusi keluarga yang mengandung dan melahirkan anak 
berperan penting membina anak keturunannya sebagai pendidik pertama dan utama dalam keluarga. Keluarga merupakan institusi kecil tempat anak belajar, mempelajari sifatsifat mulia, kesetiaan, kasih sayang. Dalam institusi keluarga ayah-ibu memupuk dan membentuk sikap berani, ulet, jujur, disiplin, dan karakter yang menjadi dasar dalam memasuki kehidupan di luar rumah. Kedua, mendidik dan menjaga agar terhindar dari ahli neraka (QS. at-Tahrim/66:6, QS. Thaha/20:132). Sejarah telah membuktikan bahwa bangsa yang maju adalah bangsa yang berilmu. Kemajuan tidak mungkin akan dicapai tanpa pencapaian ilmu yang tinggi. Untuk tujuan ini institusi keluarga perlu memastikan bahwa perasaan cinta terhadap ilmu ini perlu dipupuk seawal mungkin. Bermula dari rumah tangga, ayah ibu perlu menyediakan suasana yang kondusif yang dapat menggalakkan minat anak-anak kepada pertumbuhan ilmu.

Ketiga, memotivasi, mengarahkan, dan menumbuhkan semangat bahwa mereka adalah makhluq Allah swt yang diciptakan dengan berbagai kelebihan yang sempurna (QS. Al-An'am/6: 65, QS. Al-Isra'/17:70), dan disediakan pilihan beragam profesi (QS. AlZukhruf/43: 32). Institusi keluarga berkewajiban mengarahkan mereka sesuai dengan potensi dan kelebihannya dan memilih profesi dengan tujuan untuk kesejahteraan dunia dan akhirat. Keempat, mempersiapkan mereka dengan kompetensi (kognitif, psikomotorik, dan afektif) agar mampu mengemban amanah sebagai khalifah (QS. Al-Ahzab/33: 72). Institusi keluarga bertanggungjawab memastikan mereka mendapat kesempatan terbaik meningkatkan kompetensinya melalui pendidikan terbaik.

Membentuk karakter generasi muda dimulai pada institusi keluarga. Namun sebaiknya didukung oleh pendidikan karakter di sekolah dan lingkungan masyarakat. Hal ini sejalan dengan temuan Reksiana (2016) yang mengatakan sekolah, keluarga dan masyarakat (lingkungan sosial) memiliki peran yang signifikan dalam menumbuhkan karakter positif anak. Orang tua berperan aktif dalam membentuk karakter anak, masyarakat harus membiasakan anak untuk mengaplikasikan nilai-nilai karakter dalam kehidupan seharihari. Untuk pengembangan nilai karakter di sekolah. Epstein dan Mavis (2002:20) mengajukan enam tipe kemitraan yang dapat dijalin oleh orang tua dan pihak sekolah. Pertama, pengasuhan (parenting) yaitu orang tua mengkondisikan dan memiliki waktu luang di rumah agar bisa membantu siswa dalam pembelajaran dan moralitas. Kedua, komunikasi (communicating), yaitu sekolah mengkomunikasikan program yang ada di sekolah dengan orang tua dan masyarakat. Ketiga, sukarelawan (voluntering) yaitu sekolah mengajak keluarga dan masyarakat menjadi sukarelawan dalam mengembakan program di sekolah. Keempat, belajar di rumah (learning at home) yaitu dengan melibatkan keluarga dalam aktivitas akademik perencanaan tujuan dan pengambilan putusan. Kelima, membuat putusan (decision making) masyarakat memiliki andil besar dalam pengambilan putusan yang ada di sekolah. Keenam, sekolah menjalin 
kemitraan (collaborating with community), yaitu pada tahap ini staf sekolah, keluarga dan masyarakat memberikan kontribusi dalam membentuk masyarakat yang bermoral.

Penelitian Emilie Phillips Smith (2003) menguji korelasi antara faktor keluarga, sekolah, masyarakat dengan sikap rasial, etnis dan prestasi akademik. Smith menyimpulkan bahwa ketika seorang anak memiliki latar belakang ras-etnis yang baik, maka ia memiliki karakter dan akademik yang baik pula. Studi ini menunjukkan bahwa keluarga, sekolah, dan masyarakat merupakan faktor penting yang berkaitan dengan sikap rasial-etnis anak dan juga untuk prestasi akademik mereka. Penelitian Casmini (2007:47 lebih menekankan pada peran orang tua dalam membentuk karakter generasi muda. Pola asuh orang tua dalam keluarga akan berpengaruh terhadap perkembangan anak. Sikap perilaku dan kebiasaan orang tua sehari-hari akan dilihat, dinilai dan ditiru oleh anakanaknya, sehingga mereka akan berperilaku seperti orang tuanya. S. E. Oladipo (2009:149-156) mengungkapkan bahwa pendidikan moral anak dibagi berdasarkan pembagian tanggung jawab. Lembaga-lembaga harus saling berinteraksi dalam memberikan pendidikan moral anak. Pendidikan moral bukan hanya tanggung jawab orang tua dan lembaga saja, tetapi semua pihak harus bertanggung jawab. Demikian pula penelitian Dewi Umayami (2013:7) menyimpulkan bahwa mengembangkan sikap kemandiriran seorang anak memerlukan metode atau pola asuh. Pemilihan metode atau pola asuh yang tepat akan mampu menimbulkan kemandirian seorang anak.

\section{KESIMPULAN}

Perubahan yang terjadi akibat kemajuan ilmu pengetahuan dan teknologi begitu pesat. Hal ini berdampak pada seluruh aspek kehidupan, tidak terkecuali kehidupan institusi keluarga. Hasil penelitian menunjukkan bahwa pola asuh yang diterapkan dalam membangun generasi berkarakter melalui institusi keluarga adalah pola asuh permissive, authoritarian, authoritative. Dalam upaya membentuk karakter generasi muda, institusi keluarga tidak lagi kondusif bagi Generasi Digital (Digital Native). Kondisi ini jika tidak disikapi dengan bijak oleh kelurga dapat berdampak buruk pada kehidupan dan masa depan generasi ini. Peranan strategis institusi keluarga penting untuk membina, mendidik, mengarahkan, dan mempersiapkan generasi digital menghadapi dunia digital perlu didukung oleh institusi lain (sekolah, kampus, lembaga swadaya masyarakat atau pemerintah). 


\section{DAFTAR PUSTAKA}

Al- Qur'an

Abdullah, Irwan. Konstruksi dan Reproduksi Kebudayaan. Cet. 4; Yogyakarta: Pustaka Pelajar, 2010.

Anderson, Ben. Imagined Communities. London: Verso, 1991.

Appadurai, Arjun. The Social Life of Things:Commodities in Cultural Perspectives. Cambridge: Cambridge University Press, 1986.

Bailon, Salvacion G. \& Araceli S. Maglaya. Family Health Nursing: The Process. Manila: UP College of Nursing, 1978.

Baumrind, Diana. The Influence of Parenting Style on Adolescent Competence and Substance Use, Journal of Early Adolescence 11, no. 1, 1991, h. 56-95, http://jea.sagepub.com/content/11/1/56.

Berger, Peter \& Thomas Luckmann. The Social Construction of Reality: A Treatise in the Sociology of Knowledge. New York: Penguin Books, 1991.

Casmini, Emotional Parenting. Yogyakarta: Pilar Media, 2007.

Cherln, A.J. Public and Private Families: An Introduction, $2^{\text {nd }}$ Ed. Boston: MacGraw Hill College, 1999.

Diana Baumrind, "The Influence of Parenting Style on Adolescent Competence and Substance Use," Journal of Early Adolescence 11, no. 1 (1991), 56-95, http://jea.sagepub.com/content/11/1/56.

Dunst, C.J., Trivette, C.M. \& Deal, A.G. Supporting and Strengthening Families: Methods, Strategies and Practise. Cambridge: Brookline Books, 1988.

During, Simon (ed.). Cultural Studies: Reader. London: Routledge, 1991.

Efobi, Anthony and Chinyelu Nwokolo, Relationship between Parenting Styles and Tendency to Bulliying Behavior among Adolescents, Journal of Education and Human Development 3, no. 1, 2014, h. 507-521, www.aripd.org/jehd.

El Hafz, Subhan. Peran Pola Asuh Otoriter terhadap Kematangan Emosi Yang Dimoderatori Oleh Kesabaran. http://journal.uad.ac.id/index.php/HUMANITAS/article/downbad/3842/2110.

Featherstone, Mike. Global Culture: Nationalism, Globalization, and Modernity. London: Sage Publication, 1990.

Fleming, J.S. Piaget, Kohlberg, Gilligan,and Others on Moral Development, http://swppr.org/Textbook/Morality.pdf .

Foster, G.M. Traditional Societies and Technological Change. New York: Harper \& Row, 1973.

Franklin, C. Expanding the Vision of the Social Constructionist Debates: Creating Relevaance for Practioners. Family in Society, 76 (7), 1995, 397-407. 
Friedmen, Jonathan. Cultural Identity and Global Process. London: Sage Publication, 1995.

Geerrtz, Clifford. Interpretation of Cultures. New York: Basic Books, 1973.

Gerungan, W. A. Psikologi Sosial. Bandung: Refika Aditama, 2010.

Giddens, Anthony. Modernity and Self Identity. Cambridge: Polity Press 1991.

Griffin, C. Representation of Youth. London: Polity Press, 1993.

Harwantiyoko dan Neltje F. Katuuk, MKDU IImu Sosial Dasar. Jakarta: Penerbit Gunadarma, 1997.

Hendrix, L. Quality and Equality in Marriage: A Cross Cultural View. Cross Cultural Research, 31 (3), 1995, 201-214.

Ihsan, Fuad. Dasar-Dasar Kependidikan. Jakarta: Rineka Cipta, 2001.

Isaacson, Walter. Tanpa tahun. Steve Jobs. Jakarta: Bentang.

Joanna Rowe Kaakinen et al. Family Health Care Nursing: Theory, Practice, and Research. Philadelphia: F. A. Davis Company, 2010.

Koesoema, Doni A. Pendidikan Karakter, Jakarta: Grasindo, 2007.

Lickona, Thomas. Pendidikan Karakter. Bantul: Kreasi Wacana, 2012.

Lury, Celia. Consumer Culture. Cambridge: Polity Press, 1996.

Majid, Abdul dan Dian Andrayani, Pendidikan Karakter Perspektif Islam. Bandung: Remaja Rosda Karya Offset, 2011.

Mulyasa, E. Menejemen Pendidikan Karakter, Bandung: Remaja Rosdakarya, 2013.

Murdock, G.P. Social structure. New York:The MacMillan Company, 1949.

Naimeh, Tri Pendidikan Karakter Kajian Dari Teori Ekologi Perkembangan, Proceedings of National Conference on Psychilogy of Islam Bandung, Indonesia:Join Conference UPI \&UPSI. 2012, www.publikasi ilmiah.ums.ac.id.

Nock, S.L. Sociology of the Family, $2^{\text {nd }}$ Rdition. Engglewood Cliffs, New Jersey: Parentice Hall, 1992.

Oladipo, S. E. Moral Education of the Child:Whose Responsibility, Journal of Social Science 20, no. 2, 2009, h. 149-156, http:/uww.krepublishers.com/02Journals/JSS/Oladipo-S-E-Tt.pdf.

Pardeck, J.T., Murphy, J.W., \& Jung, M.C. Some Implication of Postmodernism for Social Work Practice. Social Work, 39, 1994, 343-345.

Rapport, Nigel dan Joanna Overing. Social and Cultural Anthropology: They KEY Concepts. London: Routledge, 2000.

Reksiana, Pengatuh Mikrosistem Pendidikan Terhadap Karakter Remaja SMP Islam Al-Khasiyi un Cipitat Tangerang selatan, 2016. http//wwwacademia.edu/27159017/ 
Pengaruh Mikrosistem Pendidikan Terhadap Karakter Remaja SMP Islam Al-Khasiyi un Cipitat Tangerang selatan.

Santrock, John W. Perkembangan Anak. Jakarta: Gbra Aksara Pratama, 2007.

Shilling, Chris. 1991. The Body and Social Theory. London: Routledge.

Suyanto, Bagong. Masalah Sosial Anak. Jakarta: Kencana Prenada Media Group, 2014. Umayi, Dewi. Pengaruh Pola Asuh dan Interaksi Sosial terhadap Kemandirian Siswa

Siswa SMA Don Bosko Semarang, PPs Universitas Negeri Semarang: 2013.

Wibowo, Agus. Pendidikan Karakter. Yogyakarta: Pustaka Pelajar, 2012.

Williams, Mary M.Models of Character Education: Perspectives and Developmental Issues.

The Journal of Humanistic Counseling, Education and Development 39, no. 1. 2000. http://connection.ebscohost.com.

Williams, Raymond. 1988. Keywords A Vocabulary of Culture and Society. London: Fontana Press.

Willis, P. 1990. Common Culture. Milton Keynes: Open University Press.

Yusuf al-Qardhawi. 1999. Tamadun Islam: Alternatif Masa Depan, Ustaz Haji Juanda Haji Jaya (penterjemah), Selangor: Maktabah al-Qardhawi.

Zubaedi, Desain Pendidikan Karakter: Konsepsi dan Aplikasi dalam Lembaga Pendidikan. Jakarta: Karisma Putera Utama, 2012.

Zuchdi, Darmiyati. Pendidikan Karakter dengan Pendekatan Komprehensif. Yogyakarta: UNY Press, 2010. 